June $7^{\text {th }} 2010$

\title{
The Oil Company, "Partnership" and the Moralities of Giving and Receiving: Corporate Community Engagement comes to Bangladesh
}

\section{Paper presented to London School of Economic Seminar}

Visit the villages in the area that has recently become known as 'Bibiyana' in North East Bangladesh and one is struck with a paradox. The villages lie close to a large gas field operated by the multinational oil company Chevron. Named the 'Bibiyana, gas field', the plant is one of the largest in Bangladesh, where the extraction of coal and gas by foreign companies is fiercely contested at national and local levels (co-incidentally, the gas plant is opposite Nadampur, where I carried out my doctoral fieldwork in the late 1980s). Since its inauguration in 2007 'Bibiyana' has been promoted by Chevron not only for its state of the art technology but also as a show case for 'Community Engagement' and Corporate Social Responsibility, involving a range of development programmes and corporate donations. It is here that the paradox lies. Whilst a short walk through the four communities that are closest to the plant reveals a range of examples of Chevron's largess: slab latrines that were distributed to every house without sanitation, smoke free chulas (stoves), roofing and building materials for those affected by floods, a medical clinic, and the offices of the Alternative Livelihood Programme that the company funds via a local NGO, when questioned about Chevron's role in the locality many of the poorest people will tell visitors that 'They give nothing.' Meanwhile NGO fieldworkers and Chevron officials alike mutter during unguarded momentsthat despite the obvious benefits that the programmes have brought, 'the people are very demanding.' More generally, the research that I and a small team from Jahangirnagar University conducted over 2008-09 revealed significantly different stories. On the one hand, Chevron's officials painted a picture of successful partnership with 'the community', whilst on the other, many of the people we spoke to were disgruntled and critical, claiming that Chevron had not done nearly enough for them. Why should this be so?

That there is a disjunction between what people claim to give and / or receive and what they actually give and/or receive should come as no surprise to anthropologists schooled in the art of digging beneath 'taken for granted' statements of received opinion. It is, after all, hardly news that schemes of improvement, whether carried out by development agencies or multinational corporations rarely do what they set out to do or that claims of success made by donors and corporations fail to match up to reality. Rather than simply investigating the reasons 'why projects fail', anthropologists such as James Ferguson have in recent decades been asking more interesting questions concerning the 'unintended consequences' of such projects, and their relationship to power relations and governance (Ferguson, 1999). What we learn from such perspectives are the rewards of focussing upon the implicit as well as explicit messages and moralities of such schemes. As David Mosse has argued: 'What is of interest is less the relationship between policy and implementation, or dominance and resistance, and more that between hidden and public transcripts' (2005: 7).

In what follows I wish to focus specifically upon the 'transcripts' and moral orders that underlie different forms of giving and receiving in Bibiyana. By doing this I shall show how rather than being caused by locals being 'very demanding', or indeed a short fall in what's been given, the challenge facing Chevron's programmes of Community Engagement rests in a fundamental difference in two analytically separable 
moral economies which are linked to different types of gift. These are not primordial essences, marking an absolute distinction between local and global, East or West (or whatever) but arise from particular economic and political structures. On the one hand we have a weak and corrupt state which fails to provide basic needs in a context of social inequality and chronic poverty, on the other, international markets in which corporate ethics and 'reputation' has an impact upon share prices. Yet whilst both forms of giving and receiving are linked to both local and global hierarchies, they function in different ways, one aimed at creating connection and the other at disconnection.

What do these moralities involve? In the first type of giving, charity and 'helping' are underscored by Islamic moralities of social redistribution and 'helping one's own poor'; they are also an inherent aspect of local and transnational kinship relations. Here, social connectedness between expatriate patrons and their village based clients is a vital source of support for the poor, for there is no secure employment and no state provision of social protection in times of need. In the second type of exchange corporate gifts made in the name of CSR or CE aim not at long term social relations of patronage, but disconnection between givers and receivers, for formalised corporate giving is designed to satisfy a mythical state called 'sustainability' in order to gain the approval of a global and / or national audience. Both types of giving involve deeply entrenched inequalities. Yet whilst within local forms of patronage and charity givers and receivers are clearly distinguished within an established hierarchy of attendant duties and obligations, within corporate community engagement, the discursive tropes of 'partnership' and 'helping the poor to help themselves' mask the inequality (Rajak, 2008). Seeped in corporate and neoliberal moralities of individualism, self reliance and entrepreneurship, community development schemes act as forms of governance and control which seek to both quell local unrest and position the company within international codes of conduct as ethically irreproachable. In making this argument I am building upon Stirrat and Henkel's 1997 work on the 'development gift', and, more recently, Dinah Rajak's use of these perspectives to analyse CSR. (2008; forthcoming), both of which I'll return to.

\section{'Bibiyana' : A Short Background}

That Chevron's flagship Bangladeshi operation is about a quarter of a mile from the village where I have been conducting research since the late 1980s is a co-incidence, but serves as a powerful reminder of how peoples' are lives in apparently remote and rural places are bound up with global processes in multifaceted ways, drawing to our attention the complex interactions between global and local scales, or 'the grips of worldly encounters' which Anna Tsing calls 'friction': 'the awkward, unequal, unstable and creative qualities of interconnection across difference,' (Tsing, 2005:4). These 'grips of worldly encounters' have been taking place in Sylhet for centuries: rather than the story of Bibiyana involving the discovery of natural gas and subsequent dragging of otherwise isolated rural communities into the global arena via resistance to and eventual compliance with multinational companies, the story is one of on-going international connectedness. Bibiyana has, for example, had a long and intimate relationship with the global economy, via the lascars who worked on British ships from the beginning of the Twentieth Century, the men who left for Britain in their thousands from the 1960s onwards, and their families who settled in the UK with them since the 1980s. As I have described a in my other work (e.g. 1995, 1993, 2007, 2008) three of the villages surrounding the gas field are what's known locally as 'Londoni' villages, meaning that a high proportion of people have either settled in the UK or have close relatives there. Whilst now most families are increasingly orientated towards Britain, with children and grandchildren growing up who only visit Bangladesh for holidays and may not be fluent 
in Bengali (Gardner and Mand, forthcoming) the original migrants spent most of their earnings on buying up land, building houses, and transforming their status. By the 1980s, when I was doing my doctoral fieldwork, access to the local means of production (land on which to grow rice) was almost wholly based on one's access to foreign places: Londoni families owned almost all the local land whilst those families who hadn't migrated but were once large landowners had slipped down the scale to become landless or land poor. Local economic and political hierarchies were therefore dominated by relative access to the U.K. and other destinations in Europe, the US or the Middle East (show photo of houses).

These inequalities took on a distinctive local pattern, adhering to kinship networks. Whilst large and dominant lineages such as the Pathans and Syeds capitalised on the opportunities of movement to Britain and have built substantial power bases in their villages (especially Nadampur and Korimpur), in Kakura, which was originally settled by in-migrant labourers, no-one had the economic or social capital necessary for migration. Today the village is over $80 \%$ landless, far higher than the national average of 56\% (Toufique and Turton, 2006); a high preponderance of people live in mud and thatch dwellings and have no access to electricity: the power line that leads from Korimpur to Nadampur passes Kakura by. In 2008 our research found many people in Kakura, as well as in landless households in Korimpur (which for historical reasons has a high proportion of Hindus) who did not eat more than 2 meals a day, and / or who did not know where their next meal was coming from.

\section{Slide of map of area, showing villages}

Whilst British based families now largely invest money in British businesses (e.g restaurants) rather than deshi (homeland) fields, transnational migration has continued to dominate the local economy, with high amounts of dependency on remittances and / or irregular donations by UK relatives in times of need. Indeed, there is now what Steve Vertovec has described as a 'transnational habitus' in the Bibiyana area: the aspirations of young people from middle income households are almost wholly directed at getting abroad, often via marriage with British based partners. More profoundly, perhaps, the idea of bidesh (foreign places) has become core to peoples' imaginings of success, modernity and personal aspiration.

Crucially, the 'help' of Londonis is central to the livelihoods of the majority of households in the area; either in the form of regular remittances for those with a close Londoni relative, or an irregular lump sum in times of need or crisis. When we asked the poorer households how they coped in times of crisis, we learnt not only of disastrous floods, illnesses and accidents that threatened to tip them into destitution, but also how they were saved by gifts or loans from Londonis. Often the gifts flow from Londonis to their less well off kin, but they can also encompass unrelated poor, who are still encompassed by the phrase 'our own poor'. In the U.K, for example, we met a man whose family fund the education of several children from very poor unrelated families in his village. Within this context it is hardly surprising that connectedness is so important, ideally to the source of economic security that bidesh has become via the migration of oneself, or one's child or spouse. Failing this, connection to people with links to bidesh is a central survival strategy.

When natural gas was discovered the area was therefore already unusual in the Bangladeshi context for its relative wealth and strong connections to bidesh. Yet whilst remittances and 'help' from British relatives were central to the local economy, so too was agriculture. If the owners of the land lived in East London or Newcastle or Oldham, 
it did not mean that a large number of people were not dependent upon that land for their livelihoods, either by sharecropping or renting it, or because they worked as agricultural labourers. Access to land as well as to jobs on the land also come through social connections: sharecroppers are often related to land owners, or have long standing relationships with them. During my original fieldwork Kakura was a regular source of labour for the far wealthier Londoni village where I was living. In my adoptive household, labourers would be called 'mama', and support extended to their wives and children across the fields in Kakura in the way of second hand clothes, donations of fruit and veg from the garden. Long standing patron-client relations certainly involved gross inequality and exploitation, but it was also a prime source of support for the very poor, a relationship shaded with both light and dark.

The discovery of natural gas in the area took place in the mid 1990s by Occidental. By 2000 Unocal had taken over in the development of the resources; a smaller installation a few kilometres South (??) was to be joined by a much large development, in between the villages of Nadampur, Korimpur, Kakura and Firizpur, using around sixty acres of prime agricultural land.

The land was to be forcibly acquired by the Bangladeshi government and rented to Unocal, who were contracted to develop the site. Once gas was being produced it would be sold back to the government at a rate to be fixed in a 'production share contract'. In 2005 Unocal merged with Chevron, and by 2007 the gas field went into production, joining other gas fields operated by Chevron in Mouvi Bazaar and Jalalbaad. Today, Chevron produce nearly $50 \%$ of Bangladesh's gas. Their Bangladesh CEO, Steve Wilson, told me that the production share contract was 60:40 - ie, the government would take $60 \%$ of profits and Chevron $40 \%$. For 100 units of gas, the company have to give 60 to the government free of charge, the remaining 40 are sold to them; despite rumours that circulated in the days when the gas plant was being constructed, this gas is used for domestic purposes, not piped to India. Whilst executives told me that Chevron were hoping to stay in Bibiyana for at least thirty years, whether this happens is a moot point. Not only are the gas reserves rumoured to be far less than originally supposed, but the difficulties of working with the government and attendant 'risk to reputation' may make their game far more short term; earlier this year I heard rumours that they may pull out sooner rather than later.

Given the forcible loss of land, it is hardly surprising that the initial development of the gas plant met with substantial local resistance. As soon as people heard of the plans, 'Demand Resistance Committees' were set up within the different villages, and a series of demands put to Unocal: the rate of land compensation was high on the list, as was a supply of the gas (the villages do not have piped gas). A school, a hospital, a fertiliser factory and improved roads were also key. Today, people say that Unocal agreed to these stipulations; if this was the case they were making promises they could never keep: rates of compensation, the piping of gas to the communities and the siting of power plants and factories were not in their gift, but determined by the government. The negotiations took place in a context of passionate agitation: in the perspectives of landowners in particular, they were about to lose a resource which sustained not only their households but those of many people around them and which was irreplaceable; for some it seemed almost like a loss of self. As one of the biggest land losers told us: The day they grabbed my land, I lost my words. If I remember that day I have to stop myself from going mad.'

In 2005 the road was blocked by local people in an attempt to stop construction work. The police were called, threats made by the District Commissioner and writs issued. Today, one of the leaders still has a 'case' filed against him, and there are stories how those who resisted the plant were beaten by the police. Again, one must carefully 
distinguish between the role of Unocal, who had little to gain from the beatings and worse of local activists by the RAB, and the Bangladeshi state. Yet whilst some local leaders tried to hold out against the inevitable, others started to negotiate: the seeds of 'community engagement' were sown. By this time Chevron had taken over from Unocal and the compensation process was underway: this was for land and property taken in the building of the plant and the roads that surrounded it. Today Chevron say that $95 \%$ of land-owners were properly compensated at the highest rate they could negotiate with the government; we, however, heard of many ongoing 'cases', often involving land that was already under dispute or had once been classified as 'enemy property' - Hindu land that had been passed to Muslims, especially in Korimpur.

Local grievances dovetailed the national resistance campaign against the extraction of Bangladesh's natural resources by foreign companies, co-ordinated by the National Committee to Protect Oil, Gas and Mineral Resources, Power and Ports, an activist movement run largely by Dhaka intellectuals. Indeed, the role of foreign multinationals in Bangladesh has caused serious political unrest in Bangladesh in recent years. In 2006 protests against a proposed open cast mine in Phulbari, in the North East, to be operated by Asia Energy and leave over 20000 displaced people, led to the death of 3 and injury of around a hundred when police shot into a crowd of 50000 . More recently national agitation has centred around the content of PSCs with foreign companies, with the activists arguing that these grossly exploit the country's natural resources, leading to large profits for the multinationals, generous backhanders for corrupt government officials and nothing for Bangladesh. Rumour, counter rumour, civil unrest, accusations and arrests are the order of the day in a fragile democracy marked by high levels of government corruption, secret deals with multinationals and virtually nothing in the way of accountability.

Within Bibiyana, whilst nationalist sentiment certainly played a role in activism against the plant, many people were highly ambivalent at what was happening: angry at the loss of their land, certainly, and with a strong sense that the gas was a local resource which should benefit local people, yet also hopeful that the plant would bring with it substantial economic development in the form of jobs, industry, improved infra structure etc. At first these hopes seemed to be well founded: when the site was being built, hundreds of local people gained employment as labourers, their safety training and company registration cards all implying that the plant would provide a future of secure employment. Now, however, disappointment and resentment prevail: the plant is capital, not labour intensive, and only a fraction of the original employees have retained their jobs; those that ARE employed tend to be hired via labour contractors rather directly by Chevron. They therefore have none of the benefits or security offered to the skilled workforce.

\section{Show slides of gas field Show slides of local labourers with Chevron hard hats}

As we'll see, the Community Engagement programme and its gifts have partially evolved from this situation - the loss of livelihoods to the plant, and the company's inability (or unwillingness) to provide employment. Will return to this later. First, want to consider existing moralities of gift exchange within the area ....

Will now read from chapter $4 \ldots$. 


\section{Islamic moralities of giving: Qurbani Eid: December, 2008.}

The butchers have almost finished. In place of the two bullocks that only an hour ago were innocently chewing hay in the yard, a bloodied mess of flesh, skin, and bones is heaped on the ground: the discarded horns and hooves the only tangible evidence of the creatures they once were. Happily, I missed the actual slaughter. I have, however, been watching the team of butchers skilfully skin the animals and slice them up. Now the young men of the family are piling the meat onto the banana leaves laid out on the sandy ground, ready for their ritualised distribution ${ }^{1}$. Already a few gorib (poor people) have arrived in the bari. They sit patiently on the steps, their children running excitedly around. In an hour or so about fifty or sixty people will have accumulated in the courtyard, each with a plastic bag or bowl ready to receive the meat.

\section{Insert slide}

After the meat has been cut into chunks and divided into small piles, the bari men move along the row of gorib waiting on the steps, handing each person a small amount of the mungsho (meat). The rest is sorted into various deg (large cooking pot): some for dinner this evening, and some for nearby relatives, including 'our own poor': kin who have fallen on hard times and for whom attendance at the distribution would, I'm told, be in inappropriate, a cause of sharom (shame). One such person is a well dressed woman who arrives during the sacrifice, her five year old daughter wearing western style jeans and a spangly top. The women of the house greet her warmly, for this was once her nani's (maternal grandmother) bari. Since her childhood in the nearby village of Syedpur, she tells me, her family have slipped into poverty; her husband is a lowly ticket collector on a launch. They live in Dhaka, she adds. To my surprise it transpires that this morning she and her daughter travelled the three hundred or so kilometres from Dhaka in order to receive their share of the meat, which is wrapped in plastic bags and stored in her handbag, ready for the journey home.

Once the non-related gorib have their portion, they take off in a large and happy group, heading towards the other baris in the village who are known to be performing Qurbani sacrifices. This year the spoils are somewhat reduced: the British recession and slipping rate of exchange of the pound sterling against the Bangladeshi taka has had a noticeable effect on how many bullocks can be bought with the money remitted from the U.K. Last year Russell and his brothers sent enough money for six bullocks ${ }^{2}$, Amma says; this year there are only two paid for by British money, plus another one paid for by a cousin (and member of the bari) in the U.S. For the cousins in the bari next door, there are none.

Qurbani is of course not particular to Bibyana or Bangladesh, but is the Islamic festival of sacrifice of sheep, cattle, goats or camels, performed at Eid Al-Adha, in order to share their meat between family, friends and the poor. Ideologically, it is related to the injunction of Zakah, one of the five pillars of Islam in which a proportion of an individual's wealth is distributed each year to the poor ${ }^{3}$. In Nadampur in the late 1980s this involved a proportion of the dhan (unthreshed paddy) from the harvest, which was donated to the mosque, plus the more generalised practice of giving to beggars who wandered from bari to bari asking for alms, a practice which continues today. A related practice, which I describe in detail elsewhere (Gardner, 1995) is that of the distribution of shinni, in which food such as pitha cakes (made with rice flour) shandesh or other

\footnotetext{
${ }^{1}$ According to Islam, one third of the meat should go to the household, one to relatives and friends and one third to the poor.

2 Cost of bullock for eid?

${ }^{3}$ Zakah is payable at a rate of $2.5 \%$ of most types of wealth (http://www.muslimhands.org/en/gb/zakah/; accessed $4^{\text {th }}$ December 2009)
} 
delicacies are distributed by a household in times of celebration or when special prayers are required, such as during children's exams, the birth of a child, and so on. Shinni can be paid for transnationally and offered on behalf of household members living abroad; from what I have observed it is distributed amongst relatives and neighbours, rather than being a charitable donation to the poor.

In rural Bangladesh these spiritual underpinnings to charity have a spatial dimension in which one's 'own poor' tend to be those from the vicinity of one's village; this was what the Londoni men we met in the U.K were referring to when they spoke of their desire to help their 'own people'. As I have suggested elsewhere (Gardner and Ahmed, 2009) 'degrees of relatedness', and thus the extent that claims can be made and a sense of obligation experienced are calculated according to actual kinship links as well as spatial proximity. In our research in Biswanath, for example, we found that 'help' was offered first and foremost to blood relatives, and then to village 'insiders' who, even if unrelated, were seen to be locals with long lasting relationships to their patrons.

Meanwhile 'outsider' in-migrants (abedi), who did not have the social connections, were not able to obtain any help beyond distributions at Qurbani Eid, funerals or other ritual occasions.

\section{Getting Connected: Giving and Receiving as Duty and Entitlement}

That the morality of giving is matched by a morality of receiving should come as no surprise to anthropologists schooled in Mauss, for as we know, The Gift is a social contract; all gifts must be reciprocated; if they are not, social ties are denied. As Mary Douglas puts it: '..each gift is part of a system of reciprocity in which the honour of giver and receiver are engaged.' (Douglas, 1990: viii). In the schema suggested by Mauss, societies move from an 'archaic' 'system of total services' (Mauss XX 5-6) based on gifts and receiprocity, to a modern, fragmented society in which gift giving is superseded by commercial relations. In his discussion of the 'Indian gift', Parry argues that in societies featuring an advanced division of labour and world religions with transcendent values, 'pure gifts', often in the form of charitable donations, can be thought of as aesthetic acts. Ideally these gifts should be made in secret, without any thought of worldly return; indeed, 'the ethic of intention requires that the expectation of a return in the here and now should be denied' (Parry, 1986: 467-8). A good example might be the various websites that offer a global Muslim audience the opportunity to practice Qurbani by making an on-line donation which will pay for sacrifices that take place in cyber-space, anonymous giving that only God recognises, rather than to one's 'own poor' (see, for example, www.Islamicaid.org.uk: 'For $£ 45$ we offer Qurbani on your behalf.').

What we see in Bibyana is, however, more complex. Here, Islamic moralities and practices such as Zakah and Qurbani structure and provide an ideological framework for certain forms of giving, but all gifts are embedded in local and transnational social relationships in which giving creates and recreates both hierarchy and connection. Indeed, hierarchy and connection are two sides to the same coin; neither can exist without the other, for the generous gifts of wealthy expatriate donors can never be fully reciprocated, thus placing the receivers in a subservient position. I shall return to this point later in the paper where, elaborating on Stirrat and Henkel's analysis of the 'development gift', which is supposedly 'pure' but in reality muddied by power relationships, marking givers and receivers as different and unequal, I shall show how, from the point of view of those who receive charity and / or development gifts in Bibyana, what they want and expect is connection and reciprocity, not asocial donations from anonymous donors.

If there is no 'pure' gift in Bibyana, what is reciprocated by those who receive charity and 'help'? In what we might think of as 'traditional' patron-client relations in 
Bangladesh, the donations / 'help' given by patrons are reciprocated by clients in the form of labour, political loyalty, devotion and so on ${ }^{4}$. Within this context, giving and receiving are part of a long term relationship, in which the expectations of both parties are reasonably clear. For poor women, for example, the economic support offered by wealthier kin (which is never regular or wholly predictable, but comes in the form of informal gifts, whether these are second hand saris, a bundle of rice etc) is part of a long term relationship in which gifts are reciprocated with domestic labour, prayers, and performances of devout subservience. Here then, rather than Mauss's North American potlatches or the reciprocal prestations of Melanesia in which givers and receivers compete for honour and status, giving is underlain by extreme economic inequality, plus social hierarchies in which things are given in different ways to different people, according to their membership of networks of relatedness ${ }^{5}$. Whilst gifts create and reaffirm social relationships, they also create and reaffirm social class, for connectedness takes place via hierarchy. As we have seen, poor relatives are given 'help', in the form of loans, cash, and material objects such as saris, whereas the unrelated poor are given the ritualised charity of distributions at Eid, or funerals, or a handful of rice or crumpled taka bill in the begging bowl. Their claims are clearly far less powerful than those people who are socially connected enough to be classed as 'our own poor', though it should be noted that this is a highly flexible categorisation and may include local but non-related people as well as kin.

Besides the inequality between givers and receivers of 'shahajo', a major drawback to the system is that it is inherently unstable, for it depends upon the vagaries and whims of individual patrons. This is especially the case in a context of rapid change and out-migration. Indeed, there is plenty of evidence from South Asia that suggests that industrialisation and urban migration are leading to a demise in traditional patronclientage (ref Kabeer XX). Whilst in Bibyiana transnational relationships are interwoven with elements of patronage, these are also constantly changing. Increasingly younger people do not feel the duty of their parents towards distant kin they have only met a few times, and the weight of obligation can be extremely heavy: a friend of mine who lives in Newcastle complained that the gifts and 'help' he had to distribute cost him over $f_{10000}$ each time he went to the village. He wasn't going again, he said. It was too expensive and he had to concentrate on his new restaurant. Within Bibiyana however, poorer people turn to patronage because it is often the only source of support they have. What they really want is what we all want: a secure livelihood, economic development in the form of proper roads and a regular supply of power and an accountable state which provides basic needs in the form of health, education and sanitation. It was these things people hoped Chevron might provide.

\section{The Mining Company Arrives: The Gift of Community Engagement}

In what follows I suggest that the moralities and motivations that underlie Chevron's programme of CSR in Bibiyana are fundamentally different from those I have just described. So far, we have two working models of exchange in Bibiana. The first is a system of giving in which money, goods and other forms of support are given by patrons in return for both moral virtue and the political support, labour and other services of those who receive. The gift is neither a 'pure' aesthetic act nor a contract between equals, but embedded in and reproducing inequality. The second model involves neither moral

${ }^{4}$ Ref David Lewis article on changing pc relations in b'desh, JSAD, 2008?

${ }^{5}$ See Wood, 2005 
virtue nor long term social relationships, but is one of market compensation whether financial or in kind: Chevron are using local resources and therefore must 'pay' for them, via financial compensation to land owners and the provision of jobs and economic development of the area. In very simplistic terms, the first system approximates Gregory's formulation of an exchange of inalienable objects (including money, which circulates transnationally) between interdependent transactors, and the second of alienated objects between independent transactors (Bloch and Parry, 1989: 8). In their 'development gifts' to the area, however, Chevron are fusing elements from both systems: attempting to gain the moral virtue of the 'pure gift', whilst also attempting to win the compliance of local people in order that they can extract gas via transactions which are neither straightforward compensation nor involve the long term social connections and obligations of gifts. What does this involve?

As I'll shortly demonstrate, in Chevron's Community Engagement Programmes, which adhere to the international discourses of 'sustainability' and 'helping the poor to help themselves' via individual entrepreneurship, access to micro credit and so on, Chevron are attempting to make 'pure gifts' which create virtue and, hopefully, bring them salvation. Unlike the pure gifts of the world religions that Parry discusses, however, this salvation does not take place in the next world, but in a parallel world, if you like, of the global arena and their international reputation. Like the aesthetic gifts of those seeking religious salvation, in which the gift has to be unreciprocated for it to be effective, the oil company gift must also strive to deny social relationships with those that receive it. Community Engagement Programmes thus strive to position Chevron not as locally embedded patrons with needy dependents, in which the act of giving creates a long term relationship, but as ethically minded global actors, with 'partners' in 'the 'community'. Chevron are thus aiming not at market exchange nor social connectedness, but the 'pure' gift, attempting to become morally virtuous whilst rising above the messy stuff of reciprocal and localised social relationships. If sustainability is truly their objective, then the ultimate aim and proof of success is their ability to disconnect, withdrawing funding while the projects they have initiated replicate themselves: this is the essence of sustainability. Key to this process is the planned Bibiyana Foundation, a project which aims to garner the contributions of transnational villagers for community development, with matching funding from Chevron, who hope eventually to be able to pull out, leaving a Foundation run by transnational Bangladeshis in their place. Before elaborating on this argument let us briefly depart from Bibiyana and return to the anthropological work on the 'development gift'.

In their seminal article 'The Development Gift', Stirrat and Henkel (1997) argue that despite international development orthodoxies of 'partnership', with their implications of equality and sameness, what development gifts actually do is mark difference and hierarchy. By tracing the biography of the development gift, the authors demonstrate how the 'pure' charitable gift is transformed through its journey from Northern donors to Southern NGOs into 'the currency of systems of patronage' (Stittat and Henkel, 1997: 74). This argument is developed by Dinah Rajak, who has used theories of the gift to analyse not the development gifts of donors, but CSR programmes carried out by the Anglo-American mining company in South Africa. Rather than business and markets being amoral, as suggested by Mauss, Rajak argues, CSR brings morality into business practice, allowing mining companies to extend moral authority over the places where extraction takes place via moral discourses that stress partnership, responsibility and so on. Not only do global codes of ethics act as a form of governmentality (Dolan, 2007), they also naturalise neoliberal tenets such as entrepreneurship and the role of the market whilst eliding questions of power and ecology. Rather than being a 'moral bolt on' to off-set the harsh realities of neo-liberal 
capitalism, CSR is therefore intrinsic to its workings. Indeed, the gift of CSR allows transnational corporations to remain moral whilst at the same time propounding the extension of global markets and business in the name of their moral code. Yet whilst CSR discourses of 'partnership', 'empowerment' and 'participation' allow the company to avoid charges of patronage, on the ground the politics of the gift remain, sometimes forging alliances and reducing conflict with the people surrounding the mine, but always with the power relations of giver and receiver intact (Rajak, 2008a) .

On the one hand the discourse of CSR is framed in terms of commitment to the orthodoxy of 'economic empowerment' and its attendant values of 'self help' and 'autonomy' which solicit the voluntary participation of people in attempts to shape them into ideal type market actors... on the other hand the practice of CSR emerges as embedded in the social relations of patronage and clientism which carry with them the moral bonds and coercive properties of the gift, rendering this quest for 'empowerment' elusive.' (2008b: 4)

The similarities between Rajak's South African case and Bibiyana are noteworthy. In South Africa officials also complained of people being 'too demanding'; there too, trope of partnership and community are central to the programmes. Yet there is an important difference: whilst in Bibiyana CSR is also closely linked to govenmentality and authority, Chevron has very little vested in forging long term relations of patronage with its 'communities'. Yet as I have argued, the poorer people in those communities have much to gain from the social relationships and connections implied by the gift. Whilst in Chevron's Community Engagement gifts the relationship between givers and receivers is far from equal, it cannot simply be described as one of 'patron-clientage', for within the Bangladeshi context this involves specific roles, obligations and moralities. In the analysis of CSR and other forms of development gift, we therefore need to distinguish carefully between the unequal power relations that exist between givers and receivers, and particular forms of patronage, for they are not necessarily the same.

In addition, in Bibiyana the gift of community engagement involves two distinct objectives. The first is to be a 'pure' gift in the sense that the giver gains merit but does not expect reciprocity in the form of long term relationships. The second, however, involves an expectation that the gift be reciprocated in the form of public displays of gratitude which enhance the company's international reputation. As the Director of External Affairs told me, the main aim of CE is 'reputation'. The raison d'etre of the mining corporation's gift is therefore multifaceted: to create good or better relationships with the people inhabiting the area where mining operations take place and to create corporate merit via a narrative of ethically upstanding corporate standards, aimed at shareholders and international markets, sensitive as these are to a tarnished corporate image, and disseminated globally. Community Engagement thus attempts the tough gymnastic act of successful manoeuvre on both the local and the global scale, or, put another way, of being both a pure gift creating spiritual virtue and a reciprocated gift creating social relationships. Anti mining activism informs both types of manoeuvre: placating local criticism and bad feeling is crucial if the gas field is to be kept working, for security is a major risk ${ }^{6}$, whilst corporate reputations damaged by negative publicity on the internet or international media can lose millions of dollars of business.

In offering its gifts Chevron are therefore asking for substantial returns. Not only are they creating moral merit for themselves, but their gift is expected to be reciprocated by the compliance of the local population, a shining reputation at regional and global levels, and the production of a certain kind of 'community', in which exploitation,

${ }^{6}$ Interview with Steve Wilson and Naser Ahmed of Chevron Bangladesh, 3/12/08 
desperate poverty and injustice are swept from view via schemes such as micro finance, village development committees, training schemes and so on, which aim to create via 'the community', a local population of self-reliant entrepreneurs, an ideological project that lies at the heart of the neoliberal project (Ong, 2006; Murray-Li, 2007). To illustrate how this takes place, let us turn to the programmes.

\section{Creating Corporate Merit: The Invention of Partnership and Community}

As we have seen in Bibiyana, whilst gifts / charity / shahajo (help) mark difference so too do they mark relatedness and links in social networks; within the local moral economy rather than being denied or hidden under the rhetoric of 'partnership', hierarchy and dependency are to be expected. The corporate donor however, wishing to chime with Northern moralities of equality, participation and democracy, eschews any suggestion of patronage or dependency in its self representation. Rather, the way to gain merit is via the holy grail of 'partnership'. In its statement of 'The Chevron Way', for example Chevron state:

\section{Partnership \\ We have an unwavering commitment to being a good partner focused on building productive, collaborative, trusting and beneficial relationships with governments, other companies, our customers, our communities and each other}

To have a 'partnership', one has to have communities with which to partner, and indeed, 'local leaders' to help facilitate that partnership. In the narratives of Chevron executives of the early days of community engagement, the building of friendships with these 'leaders' was central, as was the description of the area as 'our community'.

Whilst forging positive relationships is key to the merit making of community engagement officers, the schemes also carry neo-liberal moralities and can be seen as a way of imposing social order on what could potentially be chaotic and dangerous to the gas plant. This perspective chimes closely with analyses of development projects as forms of control. In her ethnography of colonial, state and donor improvement schemes in Indonesia, for example, Tanya Murray-Li argues that such schemes must be understood in Foucauldian terms as a form of governance which operates by educating desires, aspirations and beliefs, which people often don't even notice happening (Murray$\mathrm{Li}, 2007: 5$ ). By rendering what are essentially political problems (such as extreme poverty, or the loss of livelihoods to industrial development) as 'technical' issues with a range of technical solutions, projects of 'improvement' govern by the back door.

A key element of the process of control is 'problematisation', whereby a problem is identified and a solution offered. The techniques of problematisation change over the years: PRA is currently in vogue. Another element in contemporary schemes is the role of experts, who: 'focus more on the capacities of the poor than on the practices through which one group impoverishes the other.' (Murray-Li, 2007:7). As Murray Li continues: 'To govern through community requires that community be rendered technical. It must be investigated, mapped, classified, documented, interpreted. ..." (2007: 234) Seen in this light 'Community Development' is an anti-politics machine par excellence (Ferguson, 1999; Murray-Li, 2007), distracting attention from the true causes of poverty, offering technical solutions to political problems, and governing, not through discipline and authority, but the implementation of new administrative structures, edicts and bureaucratic structures, all underlain by implicit neo-liberal ideology.

${ }^{7}$ http://www.chevron.com/countries/bangladesh/inthecommunityl; accessed February $23^{\text {rd }} 2010$ 
In their accounts officials describe how the first stage of Chevron's community development programme involved the hiring of consultants and experts to 'map' the area that was soon to be referred to as 'Bibiyana' (a name I never heard during my fieldwork in Nadampur). As Naser Ahmed, the Director of External Affairs, writes of the early days of 'community relations' in Bibyana:

We told them that we were more interested to know about where their strength lay, what their capacities were, before we set out to address their needs. Our goal was always to forge a partnership with the local community to play a part in the overall development of the community. Therefore we felt the need for a strategic approach to our development plan. We conducted several studies with the help of local research organisations. We first carried out a survey to assess peoples' perception of the company. And then we went for a baseline study to assess the socioeconomic condition of the locality. The latter gave us indications of the critical needs and capacity of the community ${ }^{8}$

Later came the inevitable PRA exercises in which problems were diagnosed and the field of action delineated (Murray-Li, 2007: 246). The knowledge gained from these exercises was written up in more reports, and the 'problem' (the loss of livelihoods to the gas field/ poverty) transformed into 'project goals' :' Like all development projects the solutions offered by the reports were by definition technical in nature; once speaking the language of development it is virtually impossible to break free of its vernacular. As a result of these 'scoping exercises', project objectives began to materialise, all of which found the solutions in strengthening community and individual capacity. After participatory assessment and planning, community groups were to be formed, with organisational capacity building taking place; training in literacy and other 'productive' skills would be offered, alongside technical, supervisory and marketing support. According to an early report, the main project objectives were:
to develop productive skills through training and education for economic emancipation of the vulnerable groups in Bibiyana and provide input support to enable effective utilisation of the acquired skills
and:
to bring into being a supportive environment and a systematic process of improving livelihood through providing access to quality services, community mobilisation and increase viable and sustainable opportunities through educational interventions and production and marketing assistance to the disadvantaged people ${ }^{10}$

Key to these objectives was the setting up of Village Development Organisations (VDOs) which would involve committees of 'local leaders', who would choose beneficiaries for the credit and training. Whilst being offered supplementary training in accounting and book keeping, these VDOs are modelled on a notion of natural communities, in which leaders speak for, and know, 'the people', and in which the role of development is to strengthen and modernise these structures, provide training and improve access.

Alongside these mapping exercises, with their technical language and objectives, the area (referred to by the Head of External Affairs as 'our community') is physically

\footnotetext{
${ }^{8}$ Chevron: Bibyana Gas Field, First Anniversary Report: 2008: 11

9 The project goal was : 'to assist the Bibiyana Gas field affected households and disadvantaged people to enhance their productive potential, improving their asset base and make sustainable use of them to overcome poverty through alternative livelihood.' Alternative Livelihood Programme for Vulnerable Families of Bibiyana Annual Report, 2006-2007

10 Alternative Livelihood Programme for Vulnerable Families of Bibyana, Annual Report, 2006-2007
} 
demarcated via Chevron's Road Safety Awareness Programme. Part of this involves large billboards, which have been erected along the Sherpur-Bibiyana road to advocate road traffic safety.

\section{Show slides}

Using local children as their models, each sporting a Chevron tee shirt and hard hat, (what do they say?) the billboards are the first sign that one is entering 'Chevron Country'. It was these billboards that I first saw on visiting Nadampur in 2006. Almost immediately after turning off the Highway onto what used to be a dirt track leading for five or six miles towards Kakura and Nadampur, I was amazed to see the signage, which seemed not so much to advertise traffic safety as the presence of Chevron. A few miles later we passed a group of women labourers working on the side of the road. Within the context of rural Bangladesh, their appearance was extraordinary, for they were wearing hard hats, work boots under their saris and safety goggles. It seemed as if we had crossed the borders of a new country, a mini-state run by a transnational mining company.

I shall return to the relationship between projects of improvement and governance in a short while. For now, let us shift focus from the ways in which Chevron have created community to the 'gifts' they have offered.

\section{The Community Engagement Gift}

Whilst in the early days of Unocal gifts such as tee shirts (with the company logo) were distributed at random, the Chevron programme of Community Engagement became increasingly aimed at 'community development' and poverty alleviation. Some gifts were aimed specifically at the poorest. Slab latrines were distributed to households without hygienic sanitation ${ }^{11}$. Tin roofs and concrete pillars for low income housing were also supplied, again, sporting the Chevron logo. The company could not provide piped gas, but it distributed smoke free chulas (stoves) ${ }^{12}$. These, like other gifts, came with a price tag attached: the 'community' should contribute to their upkeep. In the case of the stoves, for instance, an NGO worker explained that when it appeared that people were not caring for them properly, they were 'sold' to recipients at a cost of two hundred taka (production costs were eight hundred taka), in order to instil a sense of ownership ${ }^{13}$. In terms of development discourse, such initiatives encourage responsibility and sustainability; seen in terms of gift exchange, the donations were supposed to be reciprocated by particular forms of behaviour and attitudes. Other gifts came with similar conditions, again, aimed at producing a sense of ownership. Two 'Smiling Sun' medical clinics were built, run by the NGO SSKS, and partly funded by the donations of Londonis. These provide diagnostic services but not medicine, with a further programme of outreach health workers, and an ambulance which could take patients to the nearest hospital in Sylhet, though at a cost. Our research in 2008 showed that the poorest households in the area did not use these services since in their view there was little point in having a diagnosis if they could not afford the prescribed medicines and, if in dire need, the fare of a $\mathrm{CNG}^{14}$ was lower than that of the ambulance. Whilst not actually building a school, the company has provided support for four high schools in the area,

\footnotetext{
${ }^{11}$ According to literature produced by Chevron, they distributed 1,300 sanitary latrines among poorer households living near the field in the first year of operations, plus another 1,400 by March 2007 (Bibiana Gas Field : 1st Anniversary Report)

12 I never saw these stoves being used; they were unsuitable for the lakri (firewood) used for cooking, I was told when I asked about a disused Chevron chula I noticed in someone's yard.

13 Personal communication from FIVDB field officer

${ }^{14}$ Scooter rickshaw, run on natural gas
} 
via the funding of teachers and teaching materials, the distribution of school uniforms and providing several hundred scholarships for pupils each year ${ }^{15}$.

The clinics and scholarships are part of Chevron's explicit objective of creating 'sustainable' development and community partnership in Bibiyana. This objective is repeated again and again in their literature, for example:

Cheuron Bangladesh will always consider itself a partner of the local people of Bibiyana in the community's effort to improve their socio-economic condition. The company would like to strengthen this partnership with a view to acbieving sustainable development in the locality ${ }^{16}$

Our goal always was to forge a partnership with the local people to play a part in the overall development of the community ${ }^{17}$

Whilst some people told us they appreciated these gifts, others told us that the costs were too high or that they were excluded from the benefits. As one man from Korimpur put it:

Chevron has established a community hospital but we don't benefit from it. What's the point if all the expenses are born by us? First you have to pay 40 taka to register, then you have to pay 20 take for every visit. None of the medicine is free. Once I used the ambulance, but to get to Sylhet it cost 1000 taka.

I should stress that these more negative responses do not mean that there are no benefits for local communities: our visits to the clinic found them being used by largely satisfied patients Rather, my point is that the aim of sustainability, in which benefits are not simply provided 'for free', are often not shared by local people. One reason for this is that rather than adhering to the model of the 'gift' (reciprocated by gratitude and particular forms of behaviour), many people see the exchange as one of payment for Chevron's use of resources. As another man put it:

\section{This company have been looting our gas whilst paying nothing to us villagers}

For some, this payment should involve Chevron taking a major role in local development. In the following analysis, made by a member of a VDO, Chevron are placed at the centre of the 'big disease' of poverty and disenfranchisement, responsible for its cure. They are not 'partners', but are placed almost in the role of the state, their responsibility for the well being of their 'communities' taken for granted.

Say you have a big disease and Chevron is giving us a Paracetemol. If the disease is big the treatment should be big too. You need a big doctor, diagnosis, operations, expensive medicine, good care and so on. But Chevron want to satisfy us by providing Paracetemol?

To be responsible for the overall well being of the population of Bibiyana is not, however, what Chevron want. As I was told by their CEO, they are neither a development organisation nor the state. Nor, indeed, would they wish to be seen as a patron. Instead, CSR is something different: ethical business practice. The reasons for the company's insistence that they are not and cannot become a patron are both local and global: at a local level, the role of patron would be politically difficult and involve an

\footnotetext{
${ }^{15}$ Bibyana Gas Field First Anniversary Report, 2008: 39

16 Ibid

17 lbid: 10
} 
unstoppable tsunami of requests. Globally, the role of patron is of course morally dubious, laying the company open to accusations of imperialism and making it impossible to assert that its relationship with 'the community' is one of consensus and partnership, thus giving them the moral right to extract natural resources (Rajak, 2008). If, as I have argued, one objective of the community engagement gift is spiritual salvation via partnership and sustainability, any evidence of patronage would muddy the gift's purity.

Over recent years, the nature of corporate gift giving has therefore changed, from the earlier distribution of tee shirts, housing materials etc, to carefully designed programmes that involve the idea of sustainability, which undermines any suggestion of patronage. The key phrase in this context, which was repeated to me by officials in Chevron, is emblazoned on a banner inside the offices of the Alternative Livelihoods programme which the company funds, and is of course a mantra of current development practice, is: 'Helping people to help themselves." ${ }^{18}$ Show slide

The ideal of self-sufficiency, close cousin to the goal of 'partnership', is rarely questioned in development circles. Who, after all, wants to create dependency? Shouldn't resources be used to 'empower' people to do things for themselves? As Steve Wilson told me, the locals of Bibiana 'are a proud people', who eschew hand-outs and want to be helped-tohelp-themselves:

\section{You know ... "give a man a fishing rod" ..."}

It is this ethos which underlies The Alternative Livelihoods Programme funded by Chevron and managed by a local NGO, Friends in Village Development Bangladesh. The programme was initiated with the explicit aim of avoiding the situation that had arisen after land compensation was given in the North Pad (Koshbar) a few years earlier. As the Head of External Affairs recounted, at the time Unocal had simply paid the landowners compensation. Rather than leading to community compliance, however, the policy had led to huge anger at the company. The first problem was that the landowners had quickly spent the compensation money and now had no means of livelihood. The second was that a large number of people, who use land but don't own it, had lost their livelihoods but been given no compensation. The Alternative Livelihoods Programme (ALP) was therefore devised to meet their needs. According to this account, ALP is therefore an alternative form of compensation. Yet rather than a straightforward payment or the provision of jobs, ALP is seeped in the moral injunctions of the neoliberal CSR gift.

Like the majority of NGO programmes in Bangladesh, credit is the cornerstone of the $\mathrm{ALP}^{20}$. Administered by 'Village Development Organisations', loans and savings programmes are made available to small scale entrepreneurs who use the credit to fund a variety of livelihood activities: goat rearing, broiler farms, and fisheries are all examples. The programme also provides training, with the explicit aim of sustainability. VDO members are trained in accountancy so that they will eventually function without the

\footnotetext{
18 See Gronemeyer, 1993, on 'helping'. (in dev dictionary)

19 Interview notes, 03/12/08

20 As we saw in Chapter Three, many people access credit via a range of sources, including local money lenders, NGOs, and the 'help' of wealthier neighbours or relatives. The terms of NGO loans are often too difficult to meet: high interest payments, paid at very regular intervals, and coercive NGO officials, for whom repayment is a sign of 'success', were all mentioned to us by informants. The ALP programme was viewed relatively favourably: it had more flexible terms of repayment than, say, The Grameen Bank, which also operates locally.
} 
support of FIVDB, and borrowers in goat rearing, beef fattening, etc. There is also an adult literacy programme in Kakura, and a sewing programme for local women, in which training is given on sewing machines and a market supplied for the pieces of embroidery that the women produced ${ }^{21}$.

The ALP and other Chevron funded initiatives therefore have the avowed aim of producing self reliant entrepreneurs with access to markets, education and health care services, all of which they must contribute to in order to avoid dependency and create local self-reliance and self-discipline. The programmes are not largely aimed at the poorest (one needs land for beef fattening, broiler farms and fisheries). Nor are they aimed at 'empowerment', despite the utterances of Chevron officials, who also told me that the ALP's aim was to 'empower' people ${ }^{22}$. Rather, Chevron's Community Engagement Gift(s) come, like a Trojan Horse, with the imperatives and norms of neoliberal capitalism: individual entrepreneurship, self-reliance, access to credit and meritocratic reward are amongst its hallmarks. With its stress on credit, training, and improving access to markets for those with the greatest capacity, the programme neatly replicates the unspoken norms of neo-liberal capitalism, described by Ong as populated by 'free individuals who are then induced to self-manage according to market principles of discipline, efficiency and competitiveness.' (2006: 4)

\section{Performing / Narrating Successful Community Engagement}

Whilst the Gift of Community Engagement involves the technologies of ideological governance and is aimed at creating a compliant community of 'partners', it can only be fully reciprocated if recipients are grateful and community engagement a success. This comes via public performances and narrations, which celebrate the giving of the gifts. It is during these performances that the 'pay back' of the Community Engagement Gift becomes most explicit. Yet whilst successful community engagement is generally performed within Bibiyana, the importance of the performances for Chevron lies in their transformation in the global arena via reports and other literature which narrate success for an international audience.

The ways in which project 'success' is constructed is the focus of David Mosse's ethnography 'Cultivating Development' (2005). Arguing that the ethnographic question for the anthropology of development should not be whether projects work, but how they work, Mosse argues that rather than being driven by policy, development interventions are driven by the need to establish and maintain relationships. In order to enrol a range of supportive actors, projects need interpretive communities, with managers frequently spending more time disseminating evidence of success than dealing with the tricky everyday problems of implementation, for: 'development success is not objectively verifiable but socially produced.' (2005: 172) VIP visits, project literature, brochures, videos are all part of the performance.

Such performances of success are central to Chevron's Community Engagement Programme in Bibiyana, and are, I suggest, aimed primarily at the 'interpretive community', comprising Bangladeshi state officials, Chevron's international executives, competing corporations and the company's shareholders. More generally, the company seeks 'good PR', both in terms of public relations within Bangladesh and internationally.

\footnotetext{
${ }^{21}$ Chevron's literature reports that 40 women were trained, but our research revealed that the programme has had mixed results. Many of the women receiving the original training were unmarried; by the time they had finished the training, however, they had married and moved elsewhere. Other women complained that embroidery work was highly labour intensive, and not sufficiently well paid to make it worth their while. One women, for example, told us that for two to three days work on a piece, she only received 25 taka.

22 REF to critique of empowerment development dictionary??
} 
A key event in the performance of success is the 'handing over ceremony.' Indeed, 'handing over' lies at the very heart of community engagement: the moment when the gift (and its payback) is made public. School rooms or NGO offices are prepared, banners erected, local, national and international dignitaries invited. The community is represented by a selection of 'local leaders' and grateful recipients. Once assembled, speeches are made, photographs taken, usually of the moment of 'hand over': the computer, sewing machine or stipend physically changing hands ${ }^{23}$. Show slide, taken from report

I am not suggesting that these performances are devoid of emotional content or coldly calculating and insincere. There can be little doubt that as well as constructing success, handing-over ceremonies produce real feelings of warmth and connection, (another payback). As one senior Chevron executive was reported to have told a local official after a ceremony held in Nadampur in 2008 to mark the Alternative Livelihoods Programme, the event was 'the second most exciting day of my life. ${ }^{24}$. There can, however, be little doubt that these events are carefully managed, a fact that has not escaped many locals. I was laughingly told by several people, for example, that the bull selected as an example of the Beef Fattening Programme had in fact been bought from outside the area. Whether or not this story is true is not the point: rather, the rumour highlights the way that such events stage success and edit out failure. Crucially, it also shows how performances of success are undercut by contesting versions of reality.

Performances need an audience if they are to be meaningful. Whilst the assembled locals and dignitaries are important participants, handing-over-ceremonies require a global audience if they are to have their full impact on 'reputation'. Why else would a small bridge, recently built in Korimpur sport a brass plate with the words: 'Bibiyana Friendship Bridge', when no-one in the village (besides visiting transnational Londonis) reads English? Show slide

Local performances of success are thus turned seamlessly into heart warming stories of partnership and community and disseminated via Chevron's PR machinery, the reports and newsletters to be downloaded at a click, received through the post for shareholders, or handed in hard copies to visitors and colleagues. For example:

Buffie Wilson, wife of Chevron Bangladesh President Steve Wilson recently made a visit to the village of Karimpur, located next to the Bibiyana Gas Field in Habiganj. Her visit heralded a brand new beginning for the families of Champa Begum and Jotsna Dev. Both women lost their bomes during the devastating flood of 2007 and in standing by the community, Chevron gave them the chance to restart their lives afresh by rebuilding their homesteads. Their homes were officially presented to the proud new owners in a simple, heart warming ceremony and $M s$ Wilson was accorded a rousing reception. Champa Begum and Jotsna Dev finally found a reason to simile after last year's floods wreaked havoc, chaos and devastation in their lives. ${ }^{25}$

In another example, a satisfied recipient of training and credit gives testimony to how the ALP has turned his life around:

I just feel exhilarated when I go to my vegetable farm. I have learned how to plant and grow vegetables and I have made sure that there will be no insect or pest attacks on my vegetables as I have learned to apply appropriate insecticide at the appropriate time. The villagers who also

\footnotetext{
23 The Chevron Bangladesh Newsletter of July 2008 contains nine such photographs, in 24 pages. 24 Informal communication, interview notes, XX. We never found out what the first most exciting day of the executive's life had involved.

${ }^{25}$ Chevron Bangladesh Newsetter, Year Y, Issue 2, July 2008
} 
received training along with me are also successfully applying the scientific method of farming and getting good results .... All my efforts are being directed to the one and only goal, which is farming ... By fulfilling this dream I will drive away poverty from my family. ${ }^{26}$

(could skip this bit) A final example shows how even land acquisition, the subject of so much bad feeling and agitation in the area, can be turned into a story of success, in which land losers celebrate their contribution to national interests and improvement:

\begin{abstract}
About fifty acres of land were acquired for the development of the Bibiyana gas field. Of which about eight acres ... used to belong to my family .... Even though our land was acquired in the national interest, I personally think that each of us has been immensely benefitted. The standard of living in our area has risen and the value of land has gone up. People of the area are also beld in high esteem because of the project ..... It is by the Grace of Allah that the development work has reached a successful end. I have lost my land, but after taking into consideration the activities centering on the field, and the future possibility of development of industries, one realises that the Bibiyana serves the greater interest of the local people...27
\end{abstract}

Poss skip Success is narrated through numbers as well as 'human interest stories'. Through reports, newsletters and power point presentations, achievements are celebrated via the recitation of numbers of stipends given, training received and so on. Again, the effect is to reduce problems of poverty, injustice and disenfranchisement to technical issues that can be solved via concrete, quantifiable measures. Indeed, competing forms of knowledge have played a major role in contestations over the role of transnational mining companies in Bangladesh. These different and at times violently opposed discourses involve different and incommensurate ways of knowing: rumour competes with the 'hard' quantitative data cited of corporate reports; qualitative anthropological research with baseline surveys. Within the construction of community engagement success, however, the net effect of so many numbers is an impression of project aims successfully achieved, though no account is given of how such calculations were made.

\title{
Journey Ends \\ From the Gift of Community Engagement to the Corporate Gift : The
}

Finally, let us consider the material goods produced by the company. These also transmit messages of community partnership and support, and are given to visitors. Here the 'gift' finally comes to rest after its complicated journey: originally offered in the form of development by the mining company to 'the community' in return for performances of partnership, community consensus, and the 'disadvantaged people of Bibiyana' being helped-to-help-themselves, the gift is converted into value via corporate narratives of success which are conveyed globally via corporate literature and further materialised in the shape of mugs, calendars, pieces of embroidery and even packets of tea. These are then passed in a quite different direction, 'upwards' (if one must) to the urban and cosmopolitan consumers whose approval the company seek. A close examination suggests that many of these gifts are aimed at urban Bangladeshi recipients, to whom helping-the-poor-to-help-themselves is perhaps less appealing than national pride and economic development.

\footnotetext{
${ }^{26}$ Matin Khan, cited in Chevron, 2008: 40

${ }^{27}$ Haj Md. Moinuddin, Bibiyana Gas Field 1 1 st Anniversary, Chevron: 43
} 
The packaging of these gifts is their very point. For example, on the front of the packet of tea we read: Tea, from the garden of Chevron's neighbourhood. On the back, we're told:

Lackatoorah Tea Estate of National Tea co. Ltd., one of the oldest tea gardens in Sylhet has been growing quality tea for the people both home and abroad for the past 125 years. Chevron, one of the world's leading resources and project development companies, has been contributing significantly to the development of Bangladesh's energy sector.

Here, the colonial history of the tea sector and its obvious parallel with the presence of Chevron and other foreign companies is elided under an image of economic productivity and contribution to national development. Similar nationalist sentiments are carried on the company calendar. Again, it is Chevron's partnership with Bangladesh the nation rather than with 'the community' that takes centre stage. Each month of the calendar is illustrated by a beautifully shot photograph of people carrying the Bangladesh flag, with a poetic quotation underneath. For example, July:

You reside eternally in the spirit,

O my homeland; for you

We are adorned with new energy

On the cover of the calendar, we read:

Human energy, leading Bangladesh with energy and spirit

... In Bangladesh, where the people are known for their resilience, Chevron seeks to identify the spirit that guides them and their actions. Bangladesh's national spirit is best exemplified by its people's desire to build a better tomorrow, to strive forward by attaining economic growth and to go beyond the odds with the overriding power of aspiration and hard work. All Bangladeshis play a role in this progressive thrust towards the future by bravely facing myriad adversities and by actively contributing to the realisation of collective goals.

\section{Conclusions}

Reducing the Gift of Community Engagement, and the moralities which underpin it to neo-liberal governance or, in more crude terms, as a way of 'buying off' local resistance to the gas plant misses the more nuanced and complex ways in which business advantage, neo-liberal ideology and PR tactics interweave with a range of moral stances, dreams and aspirations. When asked what motivated him, for example, a high level executive in Chevron Bangladesh told me that for 'work' it was the wish to promote the 'reputation' of the company, whereas at a personal level, he (like so many of his compatriots) wished to harness the might of Chevron to 'do good' for the national betterment of Bangladesh, an aspiration that via the calendar and other corporate gifts, the company seek to evoke. It is important to note that such gifts are aimed at urban and professional Bangladeshis, who visit the Dhaka offices (and carry such gifts away) not the global audience accessed via the world wide web.

The Gift of Community Engagement is thus linked to a variety of moral orders or, in Foucault's terms, 'regimes of truth', which appear in different guises at different points along its journey and are both hidden and explicit. Neo-liberal ideology figures large. The creation of a certain sort of community, made up of entrepreneurial and selfreliant consumers, is key to much of the ALP and the moral injunction to be 'sustainable'. Nationalist morality also plays a part, and is used by the company to suggest that, as a 
partner with the nation, it too seeks economic development and improvement. Whilst similar to Arjun Appadurai's 'scapes' (REF) in that they are overlapping, unbounded and not reducible to a single location, these moral orders, and the narratives they involve, become meaningful at different points in the journey of the Gift. Sustainability and helping-the-poor-to-help-themselves resonates deeply with the moralities of First World consumers, employees and opinion formers, for whom questions of ethics and certain forms of morality (for example involving rights and justice) are placed at the centre of 'good' business practice as well as personhood. That Chevron needs to promote its activities on the international and national stage as morally 'good' is not simply about governance, but also about the moral orders in which its CEOs and other high level executives operate.

What I tried to show in this paper is that this moral order, so closely linked to the neo-liberal project both globally and within Bangladesh is often at odds with the moralities of giving and receiving within Bibiyana and its transnational social fields. This is not because of 'culture clash', as the traditional development tales of 'why projects fail' often have it, in which 'culture' (or 'ignorance') is presented as an obstacle to receiving development gifts in the proper manner, but because 'shahajo' in Bibyana is deeply embedded in particular political and economic structures, wherein the state is ineffective in its provision of basic human needs and access to material livelihoods only comes via one's connection to others. In lieu of free education, medicine, roads and supplies of energy, not to say sources of regular employment, is it surprising that the inhabitants of Kakura are unreceptive to the injunction to 'help themselves'?

Moreover, Chevron is not a development agency / NGO attempting to distribute 'pure gifts' but a foreign company who, in the eyes of many of our informants, are exploiting a local natural resource who therefore 'owe' the local people their own form of 'payback' for the gas that they are extracting and the land that (via the government) they have taken. The Community Development Gift is thus being given to people who subscribe to a different version of reality: the slab latrines, ALP programmes, clinics and so on are payments, not gifts. This causes profound problems for both parties. For those receiving the payment, the price to be paid has not been set by them but by Chevron, who decide what the budget for Community Engagement will be and what form its programmes will take. It is also not an amoral or value free transaction, but as we have seen, involves many injunctions concerning the behaviour of those that receive it. This is not to say that CSR is somehow 'bad' or 'doesn't work', but rather that within the model of compensation it doesn't fit the bill, for besides financial compensation for lost land and property what local people wanted from the gas plant was what most of us want and need: jobs, working infra structure, schools medical services etc, not goats and microcredit.

For Chevron, the CSR gift is also problematic, despite their stories of success. This is because as we anthropologists know, if they are not making a payment, then they must be giving a gift and if they are giving a gift then they are, by definition involved in social relationships and connections. As we have seen, in Bibiyana, such relationships are inevitably embedded in hierarchy. Yet for Chevron to accrue moral virtue within the global arena, such hierarchies must be avoided. The company's gift thus seeks disconnection, via sustainability and helping the poor to help themselves, rather than connection.

Let me return briefly to the theories of the development and CSR gift which I described earlier. As Dinah Rajak has brilliantly demonstrated in her South African work, CSR brings morality into the supposedly amoral domain of business, allowing - in crude terms - mining companies to claim the moral high ground whilst at the same time extending control over the areas and populations in which they carry out their operations. Yet whilst the tropes of partnership, participation and empowerment bring corporate 
merit and allows the company to work alongside the South African state, they also effectively mask the real relationships that exist 'on the ground', which are essentially those of patronage (Rajak, 2008 etc)

My conclusions are slightly different from these, for the Bangladeshi context is different. Here, the state is ineffective and corrupt, as well as strapped for cash. This means that in places such as Bibiyana, people cannot rely upon it to provide infra structure, healthcare, education or social protection. Poverty levels are high, and peoples' livelihoods fragile. For the rural poor, patronage in the form of social connection to wealthy people with links to the UK has thus become a vital means of survival. Within this context, an established relationship to a patron is not seen as morally dubious, but highly desirable. Even more desirable is of course the chance of having a proper, salaried job in a multinational company, with a pension, health care and so on. Originally people hoped that Chevron would bring these opportunities, yet due to the nature of gas extraction and Chevron's use of contracted labour, it was not to be.

Chevron in Bibiyana are therefore very different from Anglo American in South Africa because they do not employ many local people, and are not interested in forging long term connections with the villages that surround them: their community liason staff, for example, are rarely seen outside the high fenced confines of the plant. Moreover, despite their rhetorics of long term commitment, they - like other multinationals - will withdraw from Bangladesh if conditions get too difficult: the government becomes impossible to work with, for example, or the risk to reputation caused by national activism against their presence too great. There is therefore very little to motivate them to establish lasting connections with the local poor, both on a practical or a moral level, for to have personalised relationships would turn them into local patrons, which would blow the moral virtue they've accumulated via their schemes of 'helping the poor to help themselves.'

It is within this context that the paradox with which I started this paper finally makes sense. Within the moralities of giving and receiving in the villages surrounding the gas plant, when people announce that Chevron 'give nothing', what they mean is that Chevron have neither compensated them for their use of local gas via the value free provision of jobs and economic development, and nor are they behaving like patrons, for their gifts are limited by the restrictions imposed by the idea of 'sustainability'. They clearly don't want to have long term charitable connections with the area, but instead are training 'local leaders' in the VDOs to take on this role, attempting to set up the Bibiyana Foundation etc. whilst their own functionaries remain closeted within their CE offices inside the plant.

Does the paradox matter? Probably not for Chevron, who via their PR machinery proceed with their stories of success, which rather than being 'fake' (or as educated Bangladeshis would have it, 'insincere') are either naïve or wilfully ignorant of local realities, depending upon how cynical one is .For the recipients of the gifts however, it matters a great deal. A few people - the 'local leaders' - have benefitting greatly from their connections to Chevron, via contracts, work and other business opportunities. The poor of Bibiyana, however, remain either the same or worse off than before, facing dwindling employment in agriculture, growing economic inequalities and a hand to mouth existence in which the only way they can feed their children is to make claims that are interpreted by others as being 'very demanding'. 